УДК 364.652 - 027.553(477)"2014/2018".355.01

DOI: $10.24144 / 2524-0609.2021 .48 .137-147$

\author{
Zhylenko Ruslan \\ Candidate of Historical Sciences, Ph.D., Associate Professor \\ Department of Sociology and Social Work \\ State University «Uzhhorod National University», Uzhhorod, Ukraine \\ ruslan.zhylenko@uznhu.edu.ua \\ ORCID ID: https://orcid.org/0000-0002-2227-4534
}

\title{
COMPARATIVE STUDY OF THE CIVIL SOCIETY ORGANIZATIONS AT THE NATIONAL LEVEL AND IN CARPATHIAN REGION OF UKRAINE
}

\begin{abstract}
The study aims to compare CSOs at the national and regional (Ukrainian part of Carpathian Euroregion) levels for possible disparities. It is mainly based on the results of secondary analysis of available official statistical and fiscal data, as well as those published in the study reports. In particular, there were analyzed the Bulletins «Activity of the Civic Associations in Ukraine» and «Indicators of United State Registry of the Companies and Organizations of Ukraine» published by the State Statistics Service of Ukraine and its regional departments during 2014-2018. Also the quantitative results of studies done by National Institute for Strategic Studies, Corestone Group and GfK Ukraine, CCC Creative Center, and other institutions were examined. Relevance to the problem of research and its regional boundaries has been employed as a main selection criterion for the secondary data used. Civil society organizations (CSOs) perform exceptional role in providing social services to the inhabitants of the Carpathian region of Western Ukraine. However, they operate in a certain environment significantly influencing respectively their sustainability and capacity to offer high quality services. Obviously, the impact of environment differs regionally, creating unequal opportunities for organizations working in diverse parts of the country. This study aimed to compare CSOs at the national and regional (Ukrainian part of Carpathian Euroregion) levels for possible disparities. The author used secondary analysis of available official statistical and fiscal data, as well as data published in the study reports. He argues that despite actually the same legal, fiscal, and political environment, there are remarkable disparities between CSOs at the national and regional levels. These discrepancies are less evident regarding number and type of operating organizations, their fields of activity but are more significant in respect to available funding and its sources, budgets, staff involved, and environment for philanthropy.
\end{abstract}

Key words: civil society organization; civil organization; charitable foundation; Carpathian Euroregion.

Introduction. The Carpathian region of Western Ukraine stands out by significant numbers of rural residents, numerous remote settlements, ethnic and religious diversity, absence of large enterprises, high level of labor migration and, to a considerable extent, by more traditional way of life, etc. This particularity explains weaknesses of the official system of social services, with the only exception of oblast centers. In many cases the system is not able to cover all those in need and does not reach out to distant localities. Additionally, socioeconomic conditions of the region explain the severity of such social problems as social orphans, unemployment, child neglect, lack of support of lonely senior age individuals, problems with addictions, etc. The Roma, one of Ukraine's most vulnerable ethnic and cultural minorities, requires special attention. Experts believe that the biggest Roma community of Ukraine, almost 100,000 people, lives in Zakarpatska oblast $[1$, c.8]

Standard social services provided by the state cannot satisfy the needs of region inhabitants; some services as it is the case with disabled individuals - simply do not reach the remote villages. Low effectiveness of state services prompted CSOs to become providers of new, innovative social services for the people in Western Ukraine. For example, significant number of familytype orphanages in Zakarpatska oblast was created by CSOs and religious organizations. They provide almost all services to homeless people; they also started the process of de-institutionalization of social services to people with mental disabilities. CSOs created alternative innovative models of rehabilitation services to drug addicts and improved services to individuals with mental and physical disabilities. The network of approximately 300 CSOs provides social services in Carpathian region. Considering significance of these organizations for the region, the issues of their sustainability, funding opportunities, and staff recruiting are becoming very important.
Literature review. Scientific studies of the civil society organizations to certain extend reflect the evolution of general perception of the civil society and its institutions in Ukraine. The works published in the early years of independence were mainly devoted to theoretical approaches to the issue $[2 ; 3 ; 4 ; 5]$, development of the legal framework $[6 ; 7]$, and relationships between the state and public intuitions with the CSOs $[8 ; 9 ; 10]$. This type of publications remains dominating even today. However, new studies have wider scope of objectives and examine the activities and role of CSOs in providing social services [11], fighting corruption [12], development of rural areas [13], sustainable development etc. [14, 15]. It is worth noting that the works analyzing different types of CSOs [16] and issues related to their funding [17, 18] and sustainability [19] also appeared. SCOs themselves undertake regular comprehensive studies of the general state of civil society in Ukraine [20]. Nevertheless, despite of significant volume of obtained data, some information is still missing. In our view, first of all this is data on SCOs activity from a regional perspective. This is important because the vast majority of SCOs is not national, but is based, operate, and provide their services in particular regions, localities, communities.

The study aims to compare CSOs at the national and regional (Ukrainian part of Carpathian Euroregion) levels for possible disparities.

The study aims to meet the following objectives: 1) to compare CSOs at the national and regional levels in respect to their numbers and main fields of activities; 2 ) to analyse possible discrepancies in human resources of CSOs at the national and regional levels; 3 ) to explore the main sources of funding of CSOs at the national and regional levels; 4) To scrutinize the impact of legal framework and environment for philanthropy on CSOs operating at the national and regional levels.

Research methods. The experts highlight extreme complications with the study of the Civil Society 
Organizations in Ukraine. This is connected to the mixture of the international, regional (the EU), and national standards, systems, and statistical approached used in the country. For example, statistical data can be structured based on the type of economic activity, on the officially defined sector of economy, on legal or fiscal status, on the field of activity etc. In its turn, it leads to significant differences in data presented in various sources. Moreover, according to the bulletin «Civil Organizations» only 40 per cent of this type of CSOs submits statistical reporting data regularly $[20$, p.26]. The access to statistical data of other types of organizations is limited. Generalizing both nation legislation and international standards the experts consider 19 groups of organizations, some of them consists of several types of institutions, as the Civil Society Organizations in Ukraine. Moreover there is a discussion whether political parties should be added on the list [20, p.27]. This study is actually contains analyses of data related to two types of CSOs in Ukraine, which are civil organizations (COs) and charitable foundations (CFs). It is mainly based on the results of secondary analysis of available official statistical and fiscal data, as well as those published in the study reports. In particular, there were analyzed the Bulletins «Activity of the Civic Associations in Ukraine» and "Indicators of United State Registry of the Companies and Organizations of Ukraine» published by the State Statistics Service of
Ukraine and its regional departments during 2014-2018. Also the quantitative results of studies done by National Institute for Strategic Studies, Corestone Group and GfK Ukraine, CCC Creative Center, and other institutions were examined. Relevance to the problem of research and its regional boundaries has been employed as a main selection criterion for the secondary data used.

Results and Discussion.

Number of registered COs in the country vs. in the region. Unfortunately, mentioned above differences in the methodology are reflected even in the official statistics. Data provided by the State Statistics Service of Ukraine in the bulletin "Activity of the Civic Associations in Ukraine» and in the «Indicators of United State Registry of the Companies and Organizations of Ukraine» significantly differ. For example, in the first case 67911 civil organizations are shown in Ukraine [21] however in the second case this figure is 64526 [22, p.15] as for 2015 (Table 1). Obviously, the first figure shows number of legally registered organizations but the second one is tax related and represents active COs. Nevertheless, both data demonstrate the same trends, in particular: steady increase in number of civil organizations in the oblasts which belong to Carpathian Euroregion and a slump in general number of COs in Ukraine in 2015, which was overcome in 2018 only. Certainly this decrease was caused by annexation of Crimea and occupation of the parts of Donetsk and Lugansk regions.

Table 1.

Number of registered COs in the country vs. in the region

\begin{tabular}{|l|c|c|c|c|c|}
\hline & $\mathbf{0 1 . 0 1 . 2 0 1 4}$ & $\mathbf{0 1 . 0 2 . 2 0 1 5}$ & $\mathbf{0 1 . 0 1 . 2 0 1 6}$ & $\mathbf{0 1 . 0 1 . 2 0 1 7}$ & $\mathbf{0 1 . 0 1 . 2 0 1 8}$ \\
\hline Civil Organizations of Ukraine [21] & 77286 & 64526 & 70321 & 75988 & 82629 \\
\hline CO of Zakarpatska oblast [23] & 2215 & 2319 & 2051 & 2173 & 2266 \\
\hline CO of Lvivska oblast [24] & 4912 & 5224 & 4825 & 5351 & 5714 \\
\hline CO of Ivano-Frankivsk oblast [25] & $\mathrm{n} / \mathrm{a}$ & 2118 (April 1) & 2262 & 2447 & 2578 \\
\hline CO of Chernivtsi oblast [26] & $\mathrm{n} / \mathrm{a}$ & $\mathrm{n} / \mathrm{a}$ & 1286 (April 1) & 1370 & 1443 \\
\hline CO of Carpathian region & - & - & 10424 & 11341 & 12001 \\
\hline
\end{tabular}

Considering population estimation, it is evident that number of civil organizations per capita is slightly higher for the country than for the region - approximately 1 per 450 people and 1 per 500 people correspondently.

Division of civil organizations by activity. The data on division of COs in Ukraine by activity is available for 2014 and previous years only (Table 2). Official statistics uses rather old reporting form which does not represent the actual activity of organization. That is why most of active associations went to the category Other civil organizations. As it was mentioned above, old reporting form is not flexible and does not reflect the modern trends in civil society development. Analyses of the data for the years before 2014 shows pretty the same picture. While more fresh data is not available it can be assumed that only two changes might happen. The main increase happened in the category Associations of veterans and disabled. Since beginning of the war more than 40 allUkrainian veterans' organizations appeared. Hundreds ( 395 by 2017) have been established at the regional and local level. Approximately the same is true about the organizations founded by or working with Internally Displaced People. Many existing organizations changed their target group to the veterans or IDPs. Anyway, existing form of reporting does not allow demonstrating this. Thus, the rapid increase in number of NGOs within the last couple of years is connected to the new socially vulnerable groups - the veterans and the IDPs. On the other hand, only few (about 5 per cent) [20, c.24] out of hundreds initiatives which appeared during the Revolution of Dignity have been formalized into organization. Anyway, most of these new organizations would rather go under the category Other civil organizations.

An analyses made by Creative Center Counterpart in 2014 provides some additional information on activities of COs. In particular, 70 per cent of organizations are involved in advocacy, 64 per cent - provide services, 38 per cent combine both mentioned activities, 83 per cent - provide trainings and educational activities, 67 per cent - provide informational services, 31 per cent - legal services, and 28 per cent - psychological services [22, c.29].

Unfortunately fresh data for the Carpathian region is absent. Nevertheless comparison of older regional data (Zakarpatska oblast in 2010) with the national data of the same period shows that they are almost identical (difference within 1 per cent per category), except a share of Organizations of ethnic and friendly relations ( 5 per cent higher in Transcarpathia), which can be easily explained by multi-national population of the region. This allows assuming with a great plausibility that the current division of the associations by activity in Carpathian Region represents the general trends of the national level, while preserves some regional features (bigger number of organizations of national minorities).

Number of registered charitable foundations in the country vs. in the region. According to the data based on the Indicators of United State Registry of the Companies and Organizations of Ukraine (actually, tax number) the following number of foundations operated in Ukraine within 2014-2018 (Table 3). 
Table 2.

Division of civil organizations by activity [27].

\begin{tabular}{|l|c|}
\hline \multicolumn{1}{|c|}{ Field of activity } & Per cent \\
\hline Organizations of ethnic and friendly relations & 2,8 \\
\hline Youth organizations & 7,8 \\
\hline Children's organizations & 2,2 \\
\hline Women's organizations & 1,9 \\
\hline Associations of veterans and disabled & 5,8 \\
\hline Civil organizations of professional orientation & 10,3 \\
\hline Environmental organizations & 3,1 \\
\hline Historical and cultural heritage protection & 0,8 \\
\hline Health and sport & 17,6 \\
\hline Outcomes of Chernobyl disaster & 0,8 \\
\hline Scientific, technical, and creative associations & 1,2 \\
\hline Education and cultural development & 6,3 \\
\hline Other civil organizations & 39,1 \\
\hline Social movements & \\
\hline
\end{tabular}

Number of charitable foundations in Ukraine [28]

\begin{tabular}{|c|c|c|c|c|}
\hline January 1,2014 & January 1,2015 & January 1,2016 & January 1, 2017 & January 1,2018 \\
\hline 14999 & 15934 & 15384 & 16837 & 17726 \\
\hline
\end{tabular}

Official statistics shows ongoing increase in number of charitable organizations. By July 1, 2018 the number of charities went up to 18095 . Meanwhile, according to the estimations of the experts of Ukrainian Philanthropists
Forum vast majority of the charitable organizations exists on the paper or perform one time activity only. They estimate the real number of active organizations as 500-1000 for the country (Table 4).

Number of Charitable foundations operating in Carpathian region.

Table 4.

\begin{tabular}{|l|c|c|c|c|c|}
\hline & January 1, 2014 & January 1, 2015 & January 1, 2016 & $\begin{array}{c}\text { January 1, } \\
\mathbf{2 0 1 7}\end{array}$ & July 1, 2018 \\
\hline Zakarpatska [23] & 595 & 611 & 528 & 559 & 614 \\
\hline Lvivska [24] & 1014 & 1114 & 1019 & 1119 & 1173 \\
\hline Ivano-Frankivska [25] & Not available & 509 (April 1, 2015) & 534 & 570 & 560 \\
\hline Chernivetska [26] & Not available & Not available & 202 (April 1, 2016) & 213 & 224 \\
\hline Carpathian region & - & - & 2283 & 2461 & 2571 \\
\hline
\end{tabular}

There is available a regional split of top 100 biggest foundations of Ukraine. Most of them (38\%) are based in Kyiv, $18 \%$ - in Central Ukraine, $17 \%$ - in Southern Ukraine, $12 \%$ - in Northern Ukraine, $10 \%$ - Western Ukraine (Carpathian region plus Ternopil, Rivne, and
Volyn oblasts), and 8\% - in Eastern Ukraine).

In respect to division of foundations by activity, the recent studies show the following dynamic of charitable funds spent in Ukraine (Table 5):

Charitable funds spent in Ukraine by activity (in \%) [28]

\begin{tabular}{|l|c|c|c|}
\hline \multicolumn{1}{|c|}{ Field } & Total & $\mathbf{2 0 1 5}$ & $\mathbf{2 0 1 6}$ \\
\hline Health & 43 & 15 & 57 \\
\hline Social protection & 40 & 59 & 31 \\
\hline Economic development (community development) & 7 & 8 & 7 \\
\hline Aid to Army & 3 & 7 & 1 \\
\hline Science and Education & 2 & 1 & 2 \\
\hline Sport & 2 & 3 & 1 \\
\hline Art and culture & 1 & 2 & 0 \\
\hline Environment and animal protection & 0 & 1 & 0 \\
\hline Other & 2 & 5 & 1 \\
\hline
\end{tabular}

The regional data is absent. Nevertheless, like in the case of civil organizations, it is very plausible that the division by activity in the region is mainly identical to the national split.

Number of employed staff of CSOs in country vs. region. Official statistical data on number of employed staff of NGOs is not available. The research done in 2014 [29, c.38] (it was repeated later but only summary is available publicly) shows that less than 41 per cent of CSOs has employed staff. Within several years the general trend demonstrates decrease in number of organizations having hired staff. In average CSO have 5 employees. There is a difference between civil (associations) and charitable (foundations) organizations. COs have in average 4 workers but foundations -6 employees. 23 per cent of CSOs have permanent staff, 23 per cent contracts staff temporally. 16 per cent of CSOs have part time staff, in 8 per cent of organizations staff works hourly, and 16 per cent of organizations hire people for one time activity. The data for 2009-2014 shows minor fluctuation of variables (within 2-4 per cent per year). It makes possible to assume that the similar situation exists 
in the sector in our days.

In our view, the current information is generally correct but does not reflect the whole picture. Indeed organization can have 5 people working for it but they are not necessarily employees. In order to minimize administrative costs, the CSOs employ only minimum of staff (quite often only director) with the minimal, allowed by legislation, wage. Other people work for the organization based on service contract. Formally, from the legal point of view, these people are not employees. Even those employed with the minimal wage usually have a service contract in addition. Thus a figure of 5 employees represents rather actual average number of people working for organization but not a number of legal employees.

The data for the Carpathian region is absent. In our view, the average figure of people working for CSO is a bit lower in the region and can be estimated as 2-4 persons.

Average budget of $N G O s$ in country vs. region. There is no available data on average budgets of NGOs in Ukraine as a whole or in the Carpathian region in particular. But basic manipulations with official data allow defining approximate figures, which represent a ratio of NGOs' incomes at the national and regional levels. In 2016 the aggregated income (from all possible sources) of Ukrainian civil organizations was 7271566800 UAH [30] (roughly EUR 242385 560). By the end of 2016 there were 75988 civil organizations. Basic mathematic operation gives a figure of EUR 3190 per organization. For sure this figure does not represent all the shades of reality. It is an average annual income per organization but not a budget. It does not take into account the number of organizations which are registered but not operating, and finally it does not reflect numerous small organizations which work completely on voluntary basis. Meanwhile it allows us to compare financial situation at the national and regional level. The same manipulations for Transcarpathia shows a figure of average annual income of NGO at the level of EUR 1389 in 2016; for Lvivska oblast - EUR 1591; for IvanoFrankivska oblast - EUR 818; for Chernivetska oblast - EUR 1462 (Table 6).

Table 6.

Approximate average annual income of COs in the country vs Carpathian region in 2016

\begin{tabular}{|l|c|}
\hline \multicolumn{1}{|c|}{ Region } & Annual income in Euro \\
\hline Ukraine & 3190 \\
\hline Transcarpathia & 1389 \\
\hline Lvivska oblast & 1591 \\
\hline Ivano-Frankivska & 818 \\
\hline Chernivetska & 1462 \\
\hline
\end{tabular}

In our view, this difference does not demonstrate an inequality between the regions of the country but mainly disparity between the capital and the province. Regardless this type of information on civil organizations is absent, the data on charitable organizations (foundations) shows that top 100 biggest organizations of Ukraine, 38 per cent of them located in Kyiv, possessed two third of all funds in the field. Moreover 5 biggest foundations operated with $1 / 3$ of all funds [28].

Funding resources of NGOs in the country vs. region. Table 7 represents official information on the funding sources of the COs in Ukraine as a whole and in four oblasts which comprise Ukrainian part of Carpathian Euroregion. The data is split by the categories defined by State Statistics Service of Ukraine and which are used by COs for quarterly reporting.

Presented above statistics (Fig. 1) suggest that funding from the national budget plays relatively insignificant role among income sources of Ukrainian COs. Nevertheless its share is higher in average through the country than in the region. On the other hand, the role of local budgets (local authorities) in funding of the COs in general is higher in the region (except Transcarpathia) than average in the country. Membership fee plays approximately the same role through the income sources both at the national and regional levels (except Transcarpathia, where its share is significantly lower). Income from charitable activity plays very significant role among sources of income both for national and regional levels. At the national level, as well as for 2 (Transcarpathia and Chernivtsi) out of 4 oblasts of the region, it is the main source of income. For others it comprises more than one third of income. Social entrepreneurship plays important role as a source of income for COs at the national level but is underdeveloped in the region. Except Transcarpathia, other sources of income (endowment, money generating activities not connected to social entrepreneurship etc.) play slightly bigger role for the regional COs than at the national level. In our view, distinctive structure of income sources of the COs of Transcarpathia (heave predominance of charity activity, mainly foreign grants and donations) can be explained by relatively easy access to foreign grants. Firstly, because of the big ratio of ethnic minorities in the population structure is attractive to foreign governments, corporate and private donors (Hungarian, Slovak, and Romanian) as well as organizations supporting Roma. Secondly, unique geographical location (the oblast borders with 4 countries, which are the EU members) makes the region eligible almost for all ENP funding programs. For comparison, other oblasts of Carpathian region usually are eligible for 1 or 2 programs only. Thirdly, in our view, the influx of foreign funds into Transcarpathia somehow over speed the institutional development of local COs. Many of them are established for one particular project of one particular foreign partner and are not willing or are not able to diversify their sources of income. For sure there are additional factors which influence the situation: distance from the capital; it is the only oblast of Ukraine with predominantly rural population and consequently relatively poor municipalities; absence of big business; strong outflow of human resources etc. It should be mentioned that most of these additional factors plays the same role for other oblasts of Carpathian region.

Table 8 and figure 2 suggest important role of foreign donors in the structure of income from charitable activity both at the national and regional level (except Ivano-Frankivs oblast). In our view, the reason is that Ivano-Frankivska oblast is not eligible for most of ENP programs (the main foreign donor). Relatively high share of people's and local companies' donations in Lviv and Ivano-Frankivsk oblasts, in our view, can be explained by long traditions of civil society development (the first NGOs were founded in the end of $19^{\text {th }}$ century) and extremely active civic position of Ukrainian GreekCatholic Church which is predominant in these two provinces. 
Funding resources of COs in Ukraine vs. Carpathian Euroregion of Ukraine, 2017 [31]

Table 7.

\begin{tabular}{|c|c|c|c|c|c|c|c|c|c|c|c|c|c|c|c|}
\hline & \multicolumn{3}{|c|}{ UKRAINE } & \multicolumn{3}{|c|}{$\begin{array}{l}\text { ZAKARPATSKA } \\
\text { OBLAST }\end{array}$} & \multicolumn{3}{|c|}{ LVIVSKA OBLAST } & \multicolumn{3}{|c|}{$\begin{array}{c}\text { IVANO- } \\
\text { FRANKIVSKA } \\
\text { OBLAST }\end{array}$} & \multicolumn{3}{|c|}{$\begin{array}{c}\text { CHERNIVETSKA } \\
\text { OBLAST }\end{array}$} \\
\hline & $\underset{\pi}{\pi}$ & 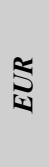 & 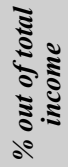 & $\underset{J}{J}$ & $\underset{1}{5}$ & 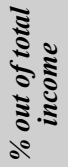 & $\underset{J}{\Xi}$ & $\sum_{1}^{\lessgtr}$ & 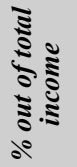 & $\underset{ָ}{ָ}$ & $\sum_{1}^{\lessgtr}$ & 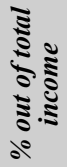 & $\underset{\pi}{\pi}$ & $\aleph_{1}$ & 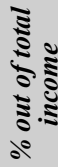 \\
\hline TOTAL & 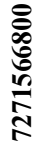 & 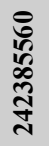 & $\stackrel{乛}{\varrho}$ & 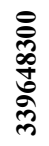 & $\begin{array}{l}\frac{0}{\sqrt{2}} \\
\text { હี } \\
=\end{array}$ & 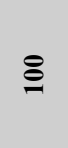 & 总 & 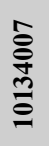 & 으 & 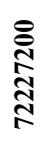 & $\begin{array}{l}\frac{n}{n} \\
\frac{1}{0}\end{array}$ & ఠ & 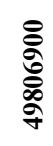 & 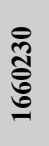 & 을 \\
\hline \multicolumn{16}{|l|}{ including: } \\
\hline $\begin{array}{l}\text { income from the state } \\
\text { (national) budget of } \\
\text { Ukraine (government, } \\
\text { ministries, } \\
\text { governmental agencies } \\
\text { etc.) }\end{array}$ & 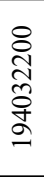 & \begin{tabular}{l}
$\stackrel{0}{t}$ \\
\multirow{2}{o}{} \\
ț
\end{tabular} & $\begin{array}{l}\infty \\
0 \\
0 \\
i\end{array}$ & 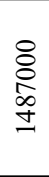 & $\begin{array}{c}\hat{\delta} \\
\stackrel{+}{q}\end{array}$ & $\stackrel{\infty}{\stackrel{\infty}{\leftrightarrow}}$ & $\begin{array}{l}8 \\
\text { ஜ } \\
\frac{m}{m}\end{array}$ & $\begin{array}{l}n \\
\delta \\
0 \\
=\end{array}$ & $\stackrel{\text { gे }}{-}$ & $\begin{array}{l}8 \\
8 \\
\stackrel{+}{+} \\
\text { ป̃ }\end{array}$ & $\begin{array}{l}8 \\
\stackrel{8}{\infty} \\
\stackrel{+}{+}\end{array}$ & $\stackrel{2}{6}$ & 0 & 0 & $\begin{array}{l}8 \\
8 \\
0\end{array}$ \\
\hline $\begin{array}{l}\text { income from the local } \\
\text { budgets }\end{array}$ & 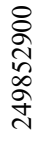 & 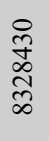 & $\begin{array}{l}\stackrel{0}{⿰} \\
\stackrel{m}{m}\end{array}$ & $\begin{array}{l}8 \\
n \\
n \\
n \\
n\end{array}$ & $\begin{array}{l}\infty \\
\infty \\
\infty \\
\infty \\
-1\end{array}$ & $\stackrel{\overbrace =}{6}$ & $\begin{array}{l}8 \\
8 \\
2 \\
2 \\
2 \\
2\end{array}$ & $\begin{array}{l}n \\
n \\
\infty \\
n \\
\infty\end{array}$ & $\begin{array}{l}n \\
\infty \\
\infty \\
\infty\end{array}$ & $\begin{array}{l}\text { ్ } \\
\text { N } \\
\text { ñ } \\
i n\end{array}$ & $\begin{array}{l}\hat{o} \\
\frac{\infty}{n} \\
n\end{array}$ & $\frac{\pi}{n}$ & 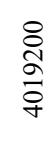 & 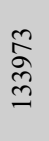 & $\underset{\infty}{\substack{0 \\
0}}$ \\
\hline membership fees & 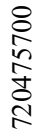 & \begin{tabular}{l}
$n$ \\
$\infty$ \\
$\infty$ \\
$n$ \\
0 \\
\multirow{2}{d}{}
\end{tabular} & 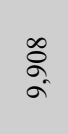 & $\begin{array}{l}8 \\
\frac{8}{8} \\
\stackrel{0}{\circ}\end{array}$ & $\begin{array}{l}\hat{2} \\
\hat{n} \\
0 \\
n\end{array}$ & ते & \begin{tabular}{l}
8 \\
8 \\
$\infty$ \\
$\infty$ \\
\multirow{1}{*}{} \\
0
\end{tabular} & 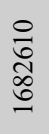 & 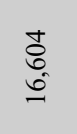 & \begin{tabular}{l}
$\stackrel{8}{8}$ \\
$\underset{+}{+}$ \\
d \\
\multirow{\infty}{+}{}
\end{tabular} & $\begin{array}{l}\infty \\
\infty \\
0 \\
0\end{array}$ & 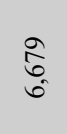 & \begin{tabular}{l}
8 \\
8 \\
\multirow{2}{1}{} \\
$\frac{1}{6}$
\end{tabular} & $\begin{array}{l}\infty \\
\substack{0 \\
0}\end{array}$ & 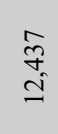 \\
\hline $\begin{array}{l}\text { income from } \\
\text { charitable activity } \\
\text { (grants, donations etc.) }\end{array}$ & 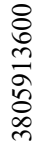 & $\begin{array}{l}\hat{\infty} \\
\hat{\infty} \\
\hat{0} \\
0 \\
0 \\
\end{array}$ & $\begin{array}{l}\text { के } \\
\text { n̂. } \\
\text { nิ }\end{array}$ & 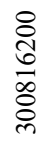 & 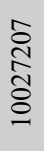 & $\begin{array}{l}\hat{0} \\
\infty \\
\infty\end{array}$ & $\begin{array}{l}8 \\
8 \\
2 \\
i \\
0 \\
0 \\
\text { ป }\end{array}$ & 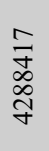 & $\begin{array}{l}\text { กิ } \\
\text { กิ }\end{array}$ & 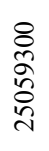 & $\begin{array}{l}0 \\
\tilde{n} \\
\infty\end{array}$ & $\begin{array}{l}2 \hat{\sigma} \\
\text { के }\end{array}$ & $\begin{array}{l}8 \\
+ \\
\infty \\
0 \\
0 \\
0\end{array}$ & 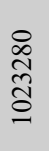 & $\frac{n}{\tilde{b}}$ \\
\hline \multicolumn{16}{|l|}{ which includes } \\
\hline $\begin{array}{l}\text { income from } \\
\text { organizations and } \\
\text { companies of Ukraine }\end{array}$ & 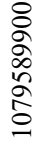 & 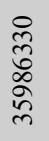 & \begin{tabular}{l}
\multirow{+}{\infty}{} \\
$\dot{ \pm}$
\end{tabular} & $\frac{8}{\frac{8}{2}}$ & $\frac{\stackrel{Ð}{m}}{\stackrel{m}{m}}$ & $\underset{\hat{N}}{\hat{N}}$ & 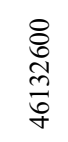 & 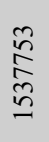 & $\frac{ \pm}{n}$ & 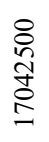 & $\begin{array}{l}\infty \\
\infty \\
\infty \\
0 \\
0 \\
\wp\end{array}$ & 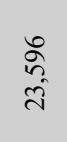 & $\begin{array}{l}8 \\
\infty \\
\infty \\
\infty \\
\infty \\
m\end{array}$ & 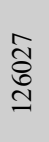 & in \\
\hline $\begin{array}{l}\text { income from the } \\
\text { citizens of Ukraine }\end{array}$ & 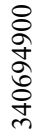 & \begin{tabular}{l}
$\hat{a}$ \\
\multirow{0}{\infty}{} \\
$\stackrel{n}{=}$
\end{tabular} & $\begin{array}{l}\mathscr{n} \\
\infty \\
\forall \\
\forall\end{array}$ & $\frac{8}{8}$ & 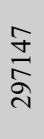 & $\begin{array}{l}\text { ๙ิ } \\
\text { i }\end{array}$ & 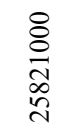 & $\begin{array}{l}\stackrel{8}{0} \\
0 \\
0\end{array}$ & $\underset{\infty}{\stackrel{q}{+}}$ & $\begin{array}{l}8 \\
8 \\
\\
0\end{array}$ & $\begin{array}{l}\hat{\sigma} \\
\sqrt[n]{2} \\
\text { }\end{array}$ & $\frac{n}{a}$ & $\begin{array}{l}8 \\
8 \\
\infty \\
0 \\
\infty \\
\infty \\
N\end{array}$ & $\begin{array}{l}\text { مे } \\
\text { d }\end{array}$ & $\underset{n}{\frac{0}{\pi}}$ \\
\hline $\begin{array}{l}\text { income from non- } \\
\text { residents (foreign } \\
\text { donors) }\end{array}$ & $\begin{array}{l}8 \\
\infty \\
\infty \\
0 \\
0 \\
\infty \\
\infty \\
\infty\end{array}$ & 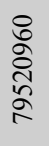 & $\begin{array}{l}\infty \\
\infty \\
\infty \\
\text { లn }\end{array}$ & 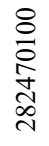 & $\begin{array}{l}\stackrel{゚}{\delta} \\
\stackrel{\hbar}{\xi}\end{array}$ & $\frac{n}{\infty}$ & 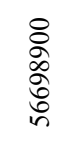 & $\begin{array}{l}3 \\
2 \\
\infty \\
\infty\end{array}$ & 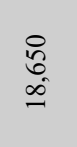 & 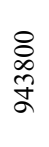 & $\frac{8}{\infty}$ & sิ & 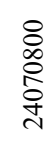 & 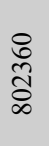 & $\begin{array}{l}\infty \\
\text { N } \\
\underset{+}{\infty}\end{array}$ \\
\hline $\begin{array}{l}\text { income from economic } \\
\text { activity of the } \\
\text { companies, established } \\
\text { by the COs to meet its } \\
\text { statutory goals (social } \\
\text { enterprises) }\end{array}$ & 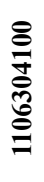 & 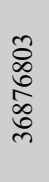 & $\begin{array}{l} \pm \\
\stackrel{\sim}{n} \\
\end{array}$ & 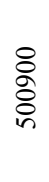 & 용 & $\frac{\mathfrak{f}}{0}$ & 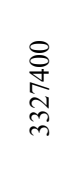 & $\stackrel{m}{g}$ & \&̊. & 0 & 0 & $\begin{array}{l}8 \\
8 \\
0\end{array}$ & $\begin{array}{l}8 \\
\frac{8}{9} \\
\frac{a}{ \pm}\end{array}$ & $\frac{\stackrel{9}{a}}{\mathfrak{a}}$ & $\begin{array}{l}\text { ภे } \\
\text { ภू }\end{array}$ \\
\hline $\begin{array}{l}\text { income from } \\
\text { other sources (f/e } \\
\text { endowment, bank } \\
\text { interest, real estate } \\
\text { rent etc.) }\end{array}$ & 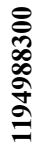 & 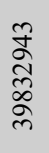 & $\begin{array}{l}\stackrel{\varpi}{~} \\
\stackrel{0}{\sigma}\end{array}$ & 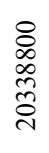 & $\frac{8}{2}$ & $\begin{array}{l}\infty \\
\infty \\
\omega^{\prime}\end{array}$ & \begin{tabular}{l}
8 \\
8 \\
0 \\
\multirow{2}{+}{} \\
నু
\end{tabular} & 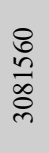 & 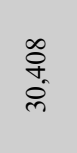 & $\begin{array}{l}8 \\
\text { ñ } \\
\delta \\
n \\
n \\
n\end{array}$ & $\begin{array}{l}\stackrel{n}{+} \\
\underset{N}{\infty}\end{array}$ & $\begin{array}{l}\infty \\
\text { mे } \\
\tilde{m}\end{array}$ & 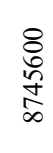 & $\frac{\text { तิ }}{\text { ते }}$ & 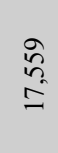 \\
\hline \multicolumn{16}{|l|}{ which includes } \\
\hline $\begin{array}{l}\text { credits from the banks } \\
\text { and other financial } \\
\text { institutions }\end{array}$ & $\begin{array}{l}\text { ठ̊̊. } \\
\text { ปे }\end{array}$ & 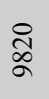 & $\begin{array}{l}\text { ¿ } \\
\stackrel{0}{0}\end{array}$ & 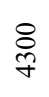 & $\stackrel{\mathscr{g}}{ \pm}$ & $\begin{array}{l}\overline{8} \\
0\end{array}$ & 0 & 0 & $\begin{array}{l}8 \\
8 \\
\circ\end{array}$ & 0 & 0 & $\begin{array}{l}8 \\
8 \\
0\end{array}$ & 0 & 0 & $\begin{array}{l}8 \\
8 \\
0\end{array}$ \\
\hline
\end{tabular}




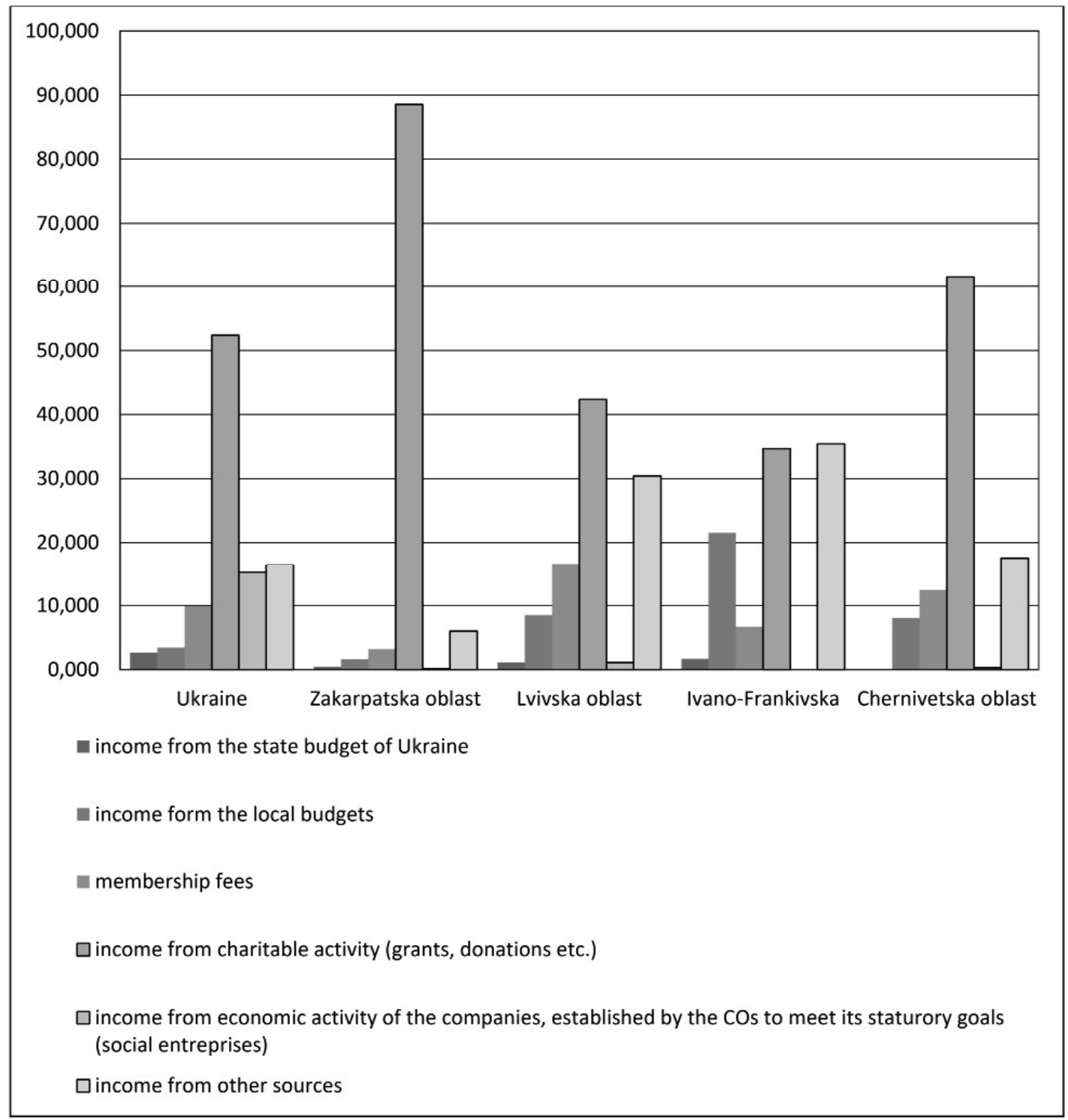

Figure 1. Funding resources of COs in Ukraine vs. Carpathian Euroregion, 2017

Legal environment and its effect on NGOs in the region. Actually the most critical, in the recent years, period of their development Ukrainian NGOs went through during the last months of president Yanukovich regime. On January 16, 2014 the parliament had passed a package of legal acts (12 laws) which became known as «Laws on Dictatorship» or «Dragon's Laws». Many of them directly or indirectly influenced the NGOs. In particular, the NGOs operated with the foreign funds were declared as a «civil association performing the function of foreign agent», there were significantly limited the civil rights on free gathering, peace protest, political activity, publishing activity. Also there were introduced severe sanctions (including criminal) for violation of the new laws. The NGOs fall under more strict control of law enforcement and tax authorities. Taking into account mentioned above funding structure of civil organizations in Ukraine, it is clear that the law on «foreign agents» threatened almost two third of organizations in Ukraine and approximately 90 per cent of civil organizations in Transcarpathia. Naturally this legislation caused mass protests and gave a new strength to the Revolution of Dignity. After the revolution, on January $28^{\text {th }}, 2014,9$ out of 12 legal acts have been canceled by the parliament, including those affected the NGOs. Actually the Law on Associations of Citizens (first passed in 2013 and then several times amended) is the main legal act regulating the activity of Ukrainian NGOs. It means that there were no any drastic changes in legal environment since 2014. Meanwhile a dozen of amendments and legal acts which mainly positively influence NGOs have been passed (better protection of property rights, improvement of registration and reregistration process, improvement of the procedure of changes in the statutory documentation, participation in civil councils (advisory and control bodies within governmental structures and local authorities), legal regulation of the activity of the branches of NGOs (they are recognized as legal entities - «separated departments»), free choice of the geographical territory of activity (regardless the place (city, region, national) of registration), improvement of cooperation with authorities etc.). Nevertheless there are several ambiguous and discursive developments. The most scandalous is introduction of income, property, and spending declaring for so-called anti-corruption NGOs in 2017. In fact they (and their top management) are obliged to declare in the same way as the public officials. Many experts consider this as a vengeance and an attempt of pressure on anti-corruption activity. Local and international organizations (including foreign governments) heavily criticize this novella. Finally it has been canceled. Also 
Sources of income from charitable activity, 2017 (in EUR)

Table 8.

\begin{tabular}{|c|c|c|c|c|c|c|c|c|c|c|}
\hline & \multicolumn{2}{|c|}{ Ukraine } & \multicolumn{2}{|c|}{ Zakarpatska oblast } & \multicolumn{2}{|c|}{ Lvivska oblast } & \multicolumn{2}{|c|}{$\begin{array}{c}\text { Ivano-Frankivska } \\
\text { oblast }\end{array}$} & \multicolumn{2}{|c|}{$\begin{array}{c}\text { Chernivetska } \\
\text { oblast }\end{array}$} \\
\hline & $\underset{\sigma}{\mathscr{c}}$ & 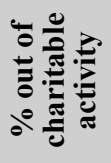 & 里 & 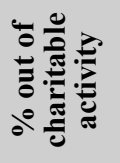 & $\underset{⿴ 囗 十)}{\sigma}$ & 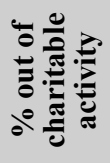 & 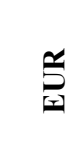 & 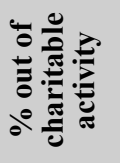 & $\underset{\varrho}{\mathscr{c}}$ & 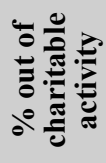 \\
\hline $\begin{array}{l}\text { income from } \\
\text { charitable } \\
\text { activity } \\
\text { (grants, } \\
\text { donations etc.) }\end{array}$ & 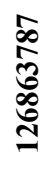 & & $\begin{array}{l}\hat{\tilde{N}} \\
\hat{\mathfrak{N}}\end{array}$ & & 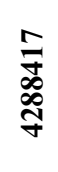 & & $\underset{\infty}{\infty}$ & & 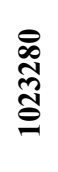 & \\
\hline \multicolumn{11}{|l|}{ which includes } \\
\hline $\begin{array}{l}\text { income from } \\
\text { organizations } \\
\text { and companies } \\
\text { of Ukraine }\end{array}$ & 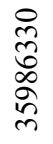 & $\begin{array}{l}0 \\
0 \\
\infty \\
\infty\end{array}$ & 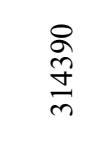 & $\frac{n}{m}$ & $\frac{n}{n}$ & $\begin{array}{l}\infty \\
\infty \\
\infty \\
n\end{array}$ & $\begin{array}{l}\infty \\
\infty \\
\infty \\
\infty \\
0\end{array}$ & $\begin{array}{l}8 \\
8 \\
\infty \\
0\end{array}$ & $\begin{array}{l}\text { ปิ } \\
\text { ป̂ }\end{array}$ & $\begin{array}{l}\frac{0}{m} \\
\stackrel{n}{n}\end{array}$ \\
\hline $\begin{array}{l}\text { income from } \\
\text { the citizens of } \\
\text { Ukraine }\end{array}$ & $\begin{array}{l}\hat{a} \\
\text { ơ } \\
\stackrel{n}{n} \\
=\end{array}$ & ๙ू & $\frac{\tilde{N}}{\hat{a}}$ & $\begin{array}{l}\text { ๙ूँ } \\
\text { ते }\end{array}$ & $\begin{array}{l}\stackrel{8}{0} \\
0 \\
0 \\
\infty\end{array}$ & $\begin{array}{l}\stackrel{0}{1} \\
0 \\
0\end{array}$ & $\begin{array}{l}\hat{\sigma} \\
i n \\
i n\end{array}$ & $\begin{array}{l}\text { ñ } \\
\text { N } \\
\text { N }\end{array}$ & $\begin{array}{l}\text { a } \\
\text { à }\end{array}$ & ก̃ \\
\hline $\begin{array}{l}\text { income from } \\
\text { non-residents } \\
\text { (foreign } \\
\text { donors) }\end{array}$ & 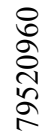 & $\begin{array}{l}\text { } \\
0 \\
\text { ஸु }\end{array}$ & $\begin{array}{l}\frac{8}{6} \\
\frac{1}{2}\end{array}$ & $\begin{array}{l}\bar{\sigma} \\
\text { nू }\end{array}$ & $\begin{array}{l}6 \\
2 \\
\infty \\
\infty\end{array}$ & $\begin{array}{l}\overrightarrow{5} \\
\dot{y}\end{array}$ & $\begin{array}{l}8 \\
\pm \\
m\end{array}$ & $\begin{array}{l}\text { m } \\
\text { m }\end{array}$ & 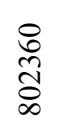 & $\underset{\substack{\forall \\
\infty}}{\exists}$ \\
\hline
\end{tabular}

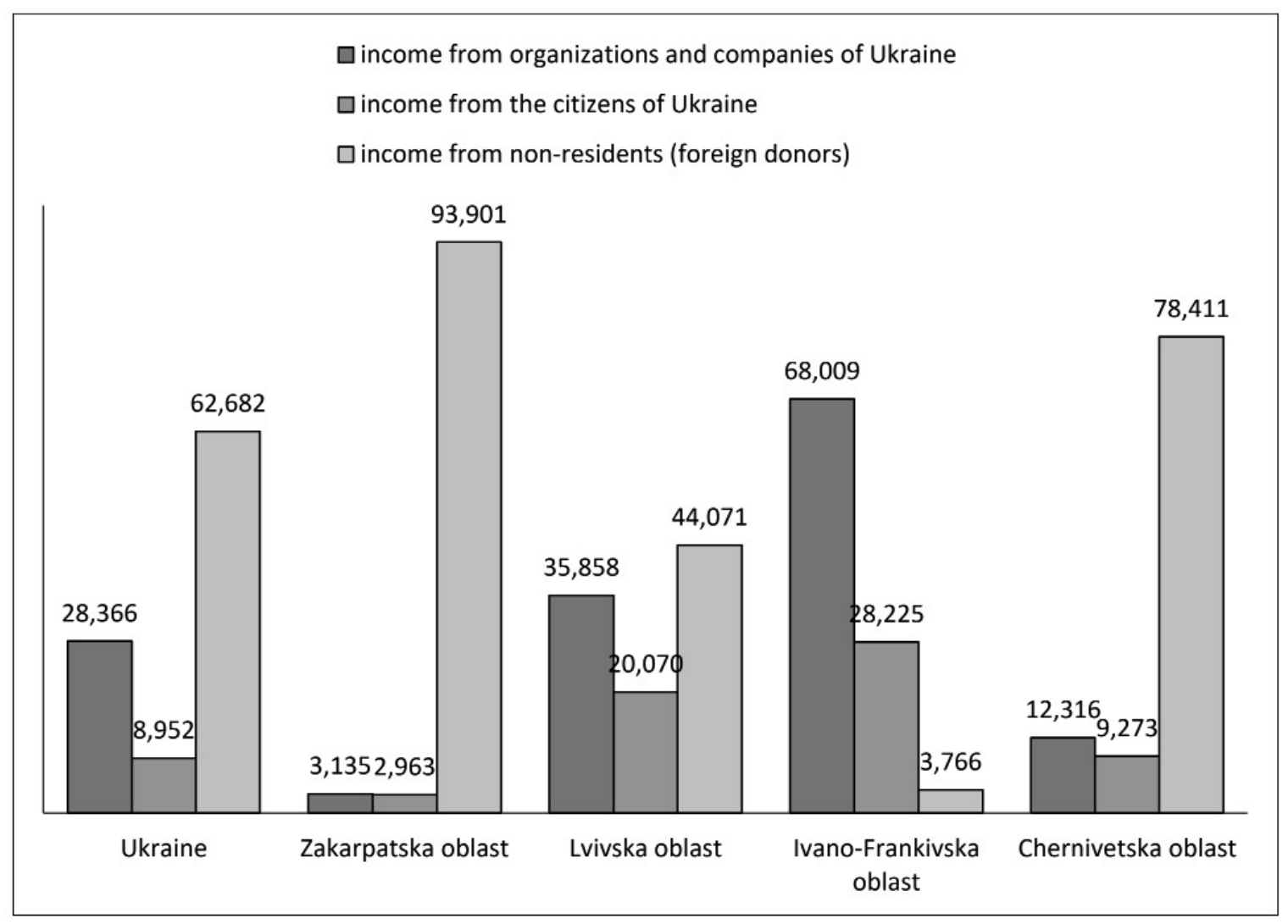

Figure 2. Income from charitable activity by sources, $2017(\%)$

there should be mentioned certain complication of the reporting forms for the Tax Authorities submitted by the non-for-profit organizations. Undoubtedly exceptional role of civil society in the Revolution of Dignity and in resistance to Russian aggression lead to passing in 2016 of the National Strategy of Promotion of Civil Society Development in Ukraine in 2016-2020. Within the strategy there was established a Coordination Council 
and developed an implementation plan for 2016-2018. During the period there were introduced the mechanism of electronic petitions, pilot version of the Unified State Portal of Administrative Services, public access to open data information, public access to electronic declarations on income, property, and spendings of officials etc. Nevertheless the experts highlight some weaknesses in implementation process, especially at the local level. The most typical are: local authorities try to limit (hide) information on their activity, unclear local plans on the Strategy implementation, and lack (in some regions - absence) of funding for particular activities within the Strategy. In our view, the main changes in legal environment of non-for-profit organizations in Ukraine were connected to introduction of the new Tax Code in 2015. Firstly, non-for-profits received more opportunities to generate income preserving their nonfor profit status (under condition that this income is spent on statutory goals of organization). Secondly, if non-for profit organization declares in time that it spent income on purposes which do not lay within its statutory goals, organization pays taxes (as a commercial company) only from the amount spent but preserves its non-forprofit status. Thirdly, based on two previous changes the non-for-profit organizations had to clarify and narrow down their statutory goals. Finally, there was changed a regulation of property issues in a case of not-for-profit organizations' closure. The property can be passed to assignee (other non-for-profit organization), spent within statutory goals or given to the state. Previously it could be shared among the members of organization. For sure it led to re-registration process in 2016-2017. Many organizations feared that the process would be complicated and would reduce the number of non-forprofit organizations. However, relatively well organized and quite simple re-registration process went smoothly. Statistics shows the on-going increase in number of civil and charitable organizations during 2016-2017 both at the national and regional levels.

In our view, there are no significant differences in impact of the legal environment at the national and regional levels. Certain otherness is rather connected to the lower awareness of both NGOs and authorities in the regions about the latest changes. For example, NGOs do not know how to fill out new reporting form and the officer in the tax office is not able to provide consultation because does not have experience to deal with it. Quite often they have to apply to the capital for clarifications and explanations.

Taxation policy for philanthropy. Taxation policy for philanthropy is one of the most actively discussed issues in the third sector of Ukraine. On one hand, national legislation (Law on Charity and Charitable Activity, Budgetary Code, and Tax Code) as well as National Strategy of Promotion of Civil Society Development in Ukraine in 2016-2020 is mainly favorable for development of philanthropy in the country. The main tools for encouragement are as follows:

- Opportunities for charitable organizations to receive funding from the national and local budgets;

- Legal entities, payers of the income tax, can claim their donations for the non-for-profit organizations as the company spending and correspondently do not pay income tax from the amount of charitable donation (money, services, other works). It is valid under condition that charitable donation does not exceed 4 per cent of previous year's taxable income;

- VAT payers do not pay VAT from the amount of charitable donation. There is the same 4 per cent limitation;

- Private persons, tax payers, have a right for tax deduction. In order to define the amount of deduction the following algorithm is used: the «pure» salary (amount of salary minus state social and pension insurances) minus amount of spending eligible for tax deduction and multiplied by the tax rate, defined by the Tax Code. Amount of spending eligible for tax deduction is accounted with the same 4 per cent limit as for the legal entities.

On the other hand, the experts consider existing system as rather complicated and, correspondently, not properly working. Mainly bigger companies use this opportunity. Smaller business and regular people prefer to donate in cash and do not declare this. Recent, big scale, events in the country (revolution, war, social problems) made existing limitation of 4 per cent irrelevant in many cases. For example wounded soldiers require medication the value of which exceeds 4 per cent of their income during the previous year. It means that either wounded soldiers or donors should pay taxes from actually charitable donation. The same situation is with the scholarship for the students (scholarships paid by philanthropists). The other discursive issue is a tax problem connected to the modern electronic means of donation (f/e SMS). The problem is that the service of mobile provider (even if it is free) is a matter of taxation. If one donates money by SMS, part of them goes for taxes of mobile provider. The other field of current discussion is connected to humanitarian aid from abroad. The recent events in the country require new type and volume of supplies from abroad (military equipment, medication etc.) which are often the matter of duty at the customs. Frankly, the authorities demonstrate commitment to solve the existing problems. The process is slow but mainly resultative.

The following observations were made as a result of the study. Broadly speaking, steady quantitative growth of the civil society organizations, civil organizations and foundations, is evident both at the national level and in the Carpathian region. Meanwhile, the Western regions of the country avoided temporary slump in number of CSOs related to foreign aggression of 2014. In respect to the COs, there has been significant increase in number of organizations which fall, according to official definition, under categories Other civil organizations and Associations of veterans and disabled. Advocacy, provision of the services, trainings and educational activities, informational, legal and psychological services are among the main activities of COs both at the national and regional levels. The only difference is related to higher number of the organizations of national minorities in Zakarpatska oblast.

In respect to the foundations, they are mainly active in the fields of health, social protection, and economic development (community development). Meantime there is a trend of gradual decrease in a share of charities operating in the field social protection and growing number of organizations dealing with health. In this context, the main disparity is related to the fact that most of the big foundations of Ukraine are located in the capital and central regions of the country.

Considering the employed staff of the CSOs, it must be pointed out that less than half of them have employed or contracted staff. In general, foundations have bigger number of employees than COs. This is correct both for the national and regional levels, but in the Carpathians the CSOs usually have two times smaller staff.

The disparities are even more evident in respect to the average budgets of NGOs at the national and regional levels. In Carpathian region they are two times smaller. Capital based organizations possess two third of all funds in the field.

Analysis of the funding sources of CSOs suggests 
differences rather within Carpathian region, than between national and regional levels. Income from charitable activity is the main source of funding at the national level as well as for the CSOs of Zakarpatska and Chernivetska oblasts. In Lvivska oblast it is still important but is well balanced by other sources. Income from organizations and companies of Ukraine is the main funding source for the CSOs in Ivano-Frankivsk oblast. The other feature of Zakarpatska and Chernivetska oblasts is a heave dependency of the organizations on the foreign funds.

Obviously since 2014 the legal environment for CSOs in Ukraine has been gradually improving. The repeal of the «Laws on Dictatorship», further improvement of the Law on Associations of Citizens, increased opportunities for income generating activities, wider access to public information are among the most evident changes. However, some weaknesses are evident in the region. They are mainly related to sometime nontransparent activities of the local authorities as well as to the lower awareness of NGOs and authorities in the regions about the latest changes.

Regardless of the encouragements for philanthropy introduced in national legislation, the environment for charity remains rather complicated and to certain extend irrelevant to modern challenges. Existing incentives work mainly for big business and are not relevant for the regions like the Carpathians, where small and middle size companies dominate. Obviously it has its impact on the activities of local CSOs, making them significantly dependent on foreign grants and donor-driven programs.

Despite actually the same legal, fiscal, and political environment, there are remarkable disparities between CSOs at the national and regional levels. These discrepancies are less evident regarding number and type of operating organizations, their fields of activity but are more significant in respect to available funding and its sources, budgets, staff involved, and environment for philanthropy.

\section{Список використаної літератури}

1. The International Charitable Organization Roma Women Fund «Chiricli» Monitoring the human rights situation of Roma in Ukraine. Country report. September 2014. p.43.

2. Неурядові організації як інститут громадянського суспільства: методологія дослідження та стан в Україні: автореф. дис... канд. політ. наук: 23.00.02 /В.І.Пащенко; НАН України. Ін-т політ. і етнонац. дослідж. К., 2005. 16 с.

3. Кольцова Д.В. Розвиток громадянського суспільства України. Економіка будівниитва і міського господарства. 2009. Випуск 5 (3). С.161-166.

4. Клименко О. Особливості механізмів діяльності організацій громадянського суспільства в країнах розвиненої демократії. Віче. 2015. Випуск 6. С.12-16.

5. Ткачук І. Світові та національні принципи організації, функціонування та фінансування організацій громадянського суспільства. Журнал європейської економіки. 2019. Випуск 18(3). С.323-335.

6. Корнієнко В.О. Правові основи громадянського суспільства сучасної України (інституційний аспект): автореф. дис. ... канд. юрид. наук : 12.00.01 / В.О.Корнієнко; Нац. ун.-т «Одеська юридична академія». Одеса, 2007. 19 с.

7. Павлюк Н.В. Удосконалення організаційно-правового механізму взаємодії інституцій публічного управління та організацій громадянського суспільства. Ефективність державного управління. 2017. № 50. С.95-102.

8. Усаченко Л.М. Співпраця органів державної влади з інститутами громадянського суспільства. Актуальні проблеми державного управління. 2009. Випуск 1. С.73-81.

9. Купрій В. Участь організацій громадянського суспільства в процесі вироблення державної політики. Суспільна політика та стратегічний менеджмент. 2008. Випуск 1. С.45-52.

10.Головенько В.А. Взаємодія органів влади та організацій громадянського суспільства як важливий чинник пом’якшення проблем соціальної нерівності. Украӥнський соиіум. 2011. Випуск 1. С.177.

11.Горемикіна Ю.В. Проблеми розвитку недержавних організацій у сфері надання соціальних послуг. 2009. ІДСД. C.161-168.

12.Сербин Р.А. Роль організацій громадянського суспільства в боротьбі 3 корупцією. Реалізація держсавної антикорупційної політики в міжнародному вимірі: матеріали V Міжнар. наук.практ. конф. (Київ, 9-10 груд. 2020 р.). Київ, 2020. Ч. 1. С.231- 234.

13.Лук'янова М.М. Роль організацій громадянського суспільства в розвитку сільських територій. Агросвіт. 2020. Випуск 11. C.127-135.

14.Клименко О. Неурядові організації і боротьба за соціально відповідальний бізнес. Політичний менеджмент. 2008. № 1 (28). C.117-127.

15.Ховрак І. Роль організацій громадянського суспільства у забезпеченні сталого розвитку. Інноваиійний розвиток та безпека підприємств в умовах неоіндустріального суспільства. Волинський національний університет ім. Лесі Українки. 2020. С.217-219.

16.Завидняк І.О. Благодійні організації як інститут громадянського суспільства. Науковий вісник Наиіонального університету державної податкової служби України (економіка, право). 2014. Випуск 2. С.74-79.

17.Павлюк К.С. Фінансове забезпечення організацій громадянського суспільства: пропозиції та альтернативи для України. Інвестииї: практика та досвід. 2013. Випуск 9. С.142-145.

18.Дем'янишина О. А., Станіславчук Н. О. Фінансування організацій громадянського суспільства в Україні. Економічні горизонти. 2017. Випуск 2 (3). С.53-59.

19.Костенко А. М. Фінансова спроможність організацій громадянського суспільства в Україні в контексті забезпечення їх інституційної спроможності. Вісник Наиіонального технічного університету Украӥни Київський політехнічний інститут. Політологія. Сочіологія. Право. 2019. № 1. С.49-54.

20.Паливода Л., Вінніков О., Купрій В. та ін. Громадянське суспільство в Україні: звіт за результатами дослідження. К.: Творчий центр ТЦК, 2016. 74 с.

21.Державна служба статистики України. Діяльність громадських об'єднань в Україні у 2015 роиі.. Статистичний бюлетень. K., 2016. URL: http://www.ukrstat.gov.ua/druk/publicat/Arhiv u/15/Arch go bl.htm (дата звернення: 11.02.2021)

22.Яблонський В.М., Балакірєва О.М., Бондар Т.В. та ін. Про стан розвитку громадянського суспільства в Україні: аналіт. доповідь. К.: НІСД, 2017. 56 с.

23.Державна служба статистики України. Головне управління статистики в Закарпатській області. Показники Єдиного державного реєстру підприємств та організаиій Украӥни (архів за 2014-1018pp.). URL: http://www.uz.ukrstat.gov.ua/ edrpou/edrpou2014.html (дата звернення: 11.02.2021)

24.Державна служба статистики України. Головне управління статистики у Львівській області. Показники Єдиного державного реєстру підприємств та організаиій Украӥни (архів за 2014-1018pp.). URL: http://www.lv.ukrstat.gov. ua/ukr/edrpoy/data_e4.php?year=2014\&id_parent=16\&ozn_sub=2\&ozn_li=4\&ind_page=edr\&pg=141 (дата звернення: $11.02 .2021)$

25.Державна служба статистики України. Головне управління статистики в Івано-Франківській області. Показники Єдиного держсавного реєстру підприємств та організацій України (архів за 2014-1018рp.). URL: http://www.ifstat.gov. 
ua/ (дата звернення: 11.02.2021)

26.Державна служба статистики України. Головне управління статистики в Чернівецькій області. Показники Сдиного державного реєстру підприємств та організацій Украӥни (архів за 2014-1018pp.). URL: http://www.cv.ukrstat.gov.ua/ (дата звернення: 11.02.2021)

27.Державна служба статистики України. Діяльність громадських об’єднань в Україні у 2014 роиі. Статистичний бюлетень. K., 2015. URL: https://ukrstat.org/uk/druk/publicat/Arhiv_u/15/Arch_go_bl.htm (дата звернення: 11.02.2021)

28.Corestone Group and GfK Ukraine. Дослідження благодійних організацій та участі населення у благодійних $i$ волонтерських проектах. 2018. URL: https://www.gfk.com/fileadmin/user_upload/dyna_content/UA/2018/2018-news/ Charity report 2017 Zagoriy Foundation.pdf (дата звернення: 11.02.2021)

29.Паливода Л, Купрій Н., Бікла О. Стан та динаміка розвитку організачій громадянського суспільства Украӥни 20022018 роки: Звіт за даними дослідження. К.: Творчий центр ТЦК, 2018. 108 с.

30. Державна служба статистики України. Діяльність громадських об'єднань в Україні у 2016 роиі. Статистичний бюлетень. К., 2017. URL: https://ukrstat.org/uk/druk/publicat/Arhiv_u/15/Arch_go_bl.htm (дата звернення: 11.02.2021)

31.Державна служба статистики України. Діяльність громадських організаиій в Украӥні у 2017 роиі. Статистичний бюлетень. К., 2018. URL: http://www.ukrstat.gov.ua/druk/publicat/kat_u/publpolit_u.htm (дата звернення: 11.02.2021)

\section{References}

1. The International Charitable Organization Roma Women Fund «Chiricli» (2014). Monitoring the human rights situation of Roma in Ukraine. Country report. September 2014.

2. Pashchenko, V.I. (2005). Neuriadovi orhanizatsii yak instytut hromadianskogo suspilstva: metodologiia doslidzhennia ta stan $v$ Ukraini [Non-governmental organizations as an institution of civil society: research methodology and their state in Ukraine] [Extended abstract of Candidate dissertation]. NAS of Ukraine. Institute of political and ethno-national research. [in Ukrainoan].

3. Koltsova, D.V. (2009). Rozvytok hromadianskogo suspilstva Ukrainy [Development of Ukraine's civil society]. Ekonomika budivnytstva i miskogo hospodarstva - Economics of construction and urban economy, 5(3), 161-166. [in Ukrainian]

4. Klymenko, O. (2015). Osoblyvosti mekhanizmiv diialnosti orhanizatsii hromadianskoho suspilstva v krainakh rozvynenoi demokratii [Distinctive features of the operational mechanisms of civil society organizations in the countries of developed democracy]. Viche, 6, 2-16. [in Ukrainian]

5. Tkachuk, I. (2019). Svitovi ta natsionalni pryntsypy orhanizatsii, funktsionuvannia ta finansuvannia orhanizatsii hromadianskoho suspilstva [International and national principles of organization, functioning, and financing of the civil society organizations]. Zurnal evropeiskoi ekonomiky, 18 (3), 323-335. [in Ukrainian]

6. Kornienko, V. (2007). Pravovi osnovy hromadianskoho suspilstva suchasnoi Ukrainy (instytutsiinyi aspekt) [Legal framework of civil society of modern Ukraine (institutional aspect]. [Extended abstract of Candidate dissertation]. Odesa Law Academy. [in Ukrainian]

7. Pavliuk, N. (2017). Udoskonalynnia orhanizatsiino-pravovoho mekhanizmu vzaemodii instytutsii publichnoho upravlinnia ta orhanizatsii hromadianskoho suspilstva [Improvement of organizational and legal mechanisms of interaction between the institutions of public administration and the organizations of civil society]. Efektyvnist derzhavnoho upravlinnia, 50, 95-102. [in Ukrainian]

8. Usachenko, L. (2009). Spivpratsia orhaniv derzhavnoi vlady z instytutamy hromadianskoho suspilstva [Cooperation of the bodies of public administration with the institutions of civil society]. Aktualni problemy derzhavnoho upravlinnia, 1, 73-81. [in Ukrainian]

9. Kuprii, V. (2008). Uchast orhanizatsii hromadianskoho suspilstva v protsesi vyroblennia derzhavnoi polityky [Participation of civil society organizations in development of public policy]. Suspilna polityka ta stratehichnyi menedzhment, 1, 45-52. [in Ukrainian]

10.Holovenko, V. (2011). Vzaemodiia orhaniv vlady ta orhanizatsii hromadianskoho suspilstva yak vazhlyvyi chynnyk pomiakshennia problem sotsialnoi nerivnosti [Cooperation of public bodies and civil society organizations as an important factor to diminish the problem of social inequality]. Ukrainskyi sotsium, 1. [in Ukrainian]

11. Horemykina, Yu. (2009). Problemy rozvyrku nederzhavnych orhanizatsii v sferi nadannia sotsialnyh posluh [Problems of development of non-governmental organizations in the social services provision field]. IDSD, 161-168. [in Ukrainian]

12.Serbin, R. (2020, December 9). Rol orhanizatsii hromadianskoho suspilstva v borotbi z koruptsieiu [Role of civil society organizations in fighting corruption]. Proceedings of International scientific-practical conference - Realizatsiia derzhavnoi antykoruptsiinoi polityky v mizhnarodnomu vymiri (pp.231-234). Part I. Kyiv. [in Ukrainian]

13.Lukianova, M. (2020). Rol orhanizatsii hromadianskoho suspilstva v rozvytku silskyh terytorii [Role of civil society organizations in development of rural territories]. Ahrosvit, 11, 127-135ю [in Ukrainia]

14.Klymenko, O. (2008). Neuriadovi organizatsii I borotba za sotsialno vidpovidalnyi biznes [Non-governmental organizations and a struggle for socially responsible business]. Politychnyi menedzhment, 1 (28), 117-127ю [in Ukrainian]

15.Khovrak, I. (2020). Rol orhanizatsii hromadianskoho suspilstva u zabezpechenni staloho rozvytku [Role of civil society organizations in provision of sustainable development]. Innovatsiinyi rozvytork ta bezpeka pidpryemsts $v$ umovakh neoindustrialnoho suspilstvaб 217-219. [in Ukrainian]

16.Zavydniak, I. (2014). Blahodiini orhanizatsii yak instytut hromadianskoho suspilstva [Charitable organizations as a civil society institution]. Naukovyi visnyk Natsionalnoho universytetu derzhavnoi podatkovoi sluzhby Ukrainy (ekonomika, parvo), 2, 74-79. [in Ukrainian].

17.Pavliuk, K. (2013). Finansove zabezpechennia orhanizatsii hromadianskoho suspilstva: propozytsii ta alternatyvy dlia Ukrainy [Financial provision of the civil society organizations: proposals and alternatives for Ukranie]. Investytsii: praktyka ta dosvid, 9, 142-145. [in Ukrainian]

18.Demianyshyna, O., \& Stanislavchuk, N. (2017). Finansuvannia orhanizatsii hromadianskoho suspilstva v Ukraini [Funding civil society organizations in Ukraine]. Ekonomichni horyzonty, 2 (3), 53-59. [in Ukrainian]

19.Kostenko, A. (2019). Finansova spomozhnist orhanizatsii hromadianskoho suspilstva v Ukraini v konteksti zabezhpechennia ikh instytutsiinoi spromozhnosti [Financial capacity of civil society organizations in Ukraine in a context of provision of their institutional capacity]. Herald of National technical university Kyiv Polytechnic Institute. Political science. Sociology. Law, 1, 49-54. [in Ukrainian]

20.Palyvoda, L., Vinnikov, O., \& Kuprii, V. (Eds.). (2016). Hromadianske suspilstvo v Ukraini: zvit za rezultatamy doslidzhennia [Civil society in Ukraine: research report]. Tvorchyi tsentr TTsK. [in Ukrainian]

21. State Statistics Service of Ukraine (2016). Diialnist hromadskykh obednan v Ukraini u 2015 rotsi [Activity of civil assosiations in Ukraine in 2015]. Statistical bulletin. http://www.ukrstat.gov.ua/druk/publicat/Arhiv u/15/Arch go bl.htm [in Ukrainian]

22.Yablonskyi, V., Balakireva, O., \& Bodnar, T. (Eds.). (2017). Pro stan hromadianskoho suspilstva $\bar{v}$ Ukraini: analitychna dopovid [About the state of civil society in Ukraine]. NISD. [in Ukrainian]

23. State Statistics Service of Ukraine. Main Department of Statistics in Zakarpatska oblast $(2014,2015,2016,2017,2018)$. Pokaznyky Edynoho derzhavnoho reestru pidpryemsts i orhanizatsii Ukrainy [Indicators of United State Registry of the Companies and Organizations of Ukraine]. http://www.uz.ukrstat.gov.ua/edrpou/edrpou2014.html [in Ukrainian] 
24.State Statistics Service of Ukraine. Main Department of Statistics in Lvivska oblast (2014, 2015, 2016, 2017, 2018). Pokaznyky Edynoho derzhavnoho reestru pidpryemsts $i$ orhanizatsii Ukrainy [Indicators of United State Registry of the Companies and Organizations of Ukraine]. http://www.lv.ukrstat.gov.ua/ukr/edrpoy/data_e4.php?year=2014\&id_parent=16\&ozn_ $\mathrm{sub}=2 \&$ ozn $\mathrm{li}=4 \&$ ind page $=$ edr\&pg $=141$ [in Ukrainian]

25.State Statistics Service of Ukraine. Main Department of Statistics in Ivano-Frankivsk oblast. (2014, 2015, 2016, 2017, 2018). Pokaznyky Edynoho derzhavnoho reestru pidpryemsts $i$ orhanizatsii Ukrainy [Indicators of United State Registry of the Companies and Organizations of Ukraine]. http://www.ifstat.gov.ua/ [in Ukrainian]

26.State Statistics Service of Ukraine. Main Department of Statistics in Chernivtsi oblast. (2014, 2015, 2016, 2017, 2018). Pokaznyky Edynoho derzhavnoho reestru pidpryemsts $i$ orhanizatsii Ukrainy [Indicators of United State Registry of the Companies and Organizations of Ukraine]. http://www.cv.ukrstat.gov.ua/ [in Ukrainian]

27. State Statistics Service of Ukraine (2015). Diialnist hromadskykh obednan v Ukraini u 2014 rotsi [Activity of civil assosiations in Ukraine in 2014]. Statistical bulletin. https://ukrstat.org/uk/druk/publicat/Arhiv u/15/Arch go bl.htm [in Ukrainian]

28.Corestone Group and GfK Ukraine (2018). Doslidzhennia blahodiinykh orhanizätsii ta uchasti naselennia u blahodiinykh $i$ volonterskykh proektakh [Study of charitable organizations and people's participation in charitable and voluntary projects]. https://www.gfk.com/fileadmin/user_upload/dyna_content/UA/2018/2018-news/Charity_report_2017_Zagoriy_Foundation. pdf [in Ukrainian]

29.Palyvoda, L., Kuprii, N., \& Bikla, O. (2018). Stan ta dynamika rozvytku orhanizatsii hromadianskoho suspilstva Ukrainy $2002-$ 2018 roky: Zvit za danymy doslidzhennia [State and Dynamic of Civil Society Development in Ukraine 2002-2013. Report on the study results]. Tvorchyi tsentr TTsK. [in Ukrainian]

30. State Statistics Service of Ukraine (2017). Diialnist hromadskykh obednan v Ukraini u 2016 rotsi [Activity of civil assosiations in Ukraine in 2016]. Statistical bulletin. https://ukrstat.org/uk/druk/publicat/Arhiv_u/15/Arch_go_bl.htm [in Ukrainian]

31.State Statistics Service of Ukraine (2018). Diialnist hromadskykh orhanizatsii v Ukraini u $\overline{2} 017$ rotsi [Activity of civil organizations in Ukraine in 2017]. Statistical bulletin. http://www.ukrstat.gov.ua/druk/publicat/kat_u/publpolit_u.htm [in Ukrainian]

Стаття надійшла до редакції 13.04.2021 p. Стаття прийнята до друку 18.04.2021 p.

Жиленко Руслан В'ячеславович

кандидат історичних наук, доцент

кафедра соціології та соціальної роботи

ДВНЗ «Ужгородський національний університет», м.Ужгород, Україна

\section{ПОРІВНЯЛЬНЕ ДОСЛІДЖЕННЯ ОРГАНІЗАЦІЙ ГРОМАДЯНСЬКОГО СУСПІЛЬСТВА НА НАЦІОНАЛЬНОМУ РІВНІ ТА В КАРПАТСЬКОМУ РЕГІОНІ УКРАЇНИ}

Анотація. Метою статті є порівняння організацій громадянського суспільства на національному та регіональному (українській частині Карпатського єврорегіону) рівнях щодо можливих диспропорцій. Організації громадянського суспільства відіграють виняткову роль в наданні соціальних послуг населенню Карпатського регіону України. Будучи більш гнучкими та наближеними до клієнтів, вони стали провідниками інноваційних підходів та, в значній мірі, забезпечили доступність послуг для вразливих груп в регіоні. Водночас цілком очевидним $є$ той факт, що організації громадянського суспільства працюють у певному середовищі, яке суттєво впливає на їх сталість та здатність надавати своєчасні та якісні послуги населенню. Природньо, що вплив середовища має регіональні особливості, а відповідно і наслідки для організацій, що працюють в різних місцевостях країни. Метою даного дослідження є порівняння організацій громадянського суспільства національного рівня і української частини Карпатського Сврорегіону. Зокрема проведень аналіз кількісного співвідношення та сфер діяльності організацій громадянського суспільства на національному та регіональному рівнях. Досліджено відмінності у кадровому забезпеченні між організаціями на згаданих рівнях. Виявлено регіональні особливості щодо джерел фінансування організацій громадянського суспільства. Охарактеризовано вплив законодавчого поля та середовища для філантропії на організації в регіоні. Автор використав переважно вторинний аналіз статистичних та фіскальних даних, а також матеріалів попередніх досліджень. Вивченню підлягали два види організацій громадянського суспільства, а саме: громадські організації та благодійні фонди. Встановлено, що незважаючи на практично ідентичне правове, фіскальне та політичне середовище, в яких працюють організації громадянського суспільства України, існують суттєві регіональні відмінності. Вони меншою мірою проявляються у кількості організацій та сферах їх діяльності, але є значно помітнішими у питаннях доступності фінансування та його джерелах, розмірах бюджету, кадрового забезпечення та середовища для філантропії. Виявленні відмінності рівною мірою можуть вказувати як на сильні сторони, так і на виклики для організацій громадянського суспільства регіону. У будь-якому разі вони повинні враховуватися в процесі організаційного розвитку, плануванні діяльності та забезпеченні сталості організацій громадянського суспільства української частини Карпатського Єврорегіону.

Ключові слова: організація громадянського суспільства; громадська організація; благодійний фонд; Карпатський Єврорегіон. 